This PDF is a selection from a published volume from the National Bureau of Economic Research

Volume Title: Financial Sector Development in the Pacific Rim, East Asia Seminar on Economics, Volume 18

Volume Author/Editor: Takatoshi Ito and Andrew K. Rose, editors

Volume Publisher: University of Chicago Press

Volume ISBN: 0-226-38684-8

Volume URL: http://www.nber.org/books/ito_07-2

Conference Date: June 22-24, 2007

Publication Date: February 2009

Chapter Title: Merger Activities and Stock Market Valuation in China

Chapter Author: Ho-Mou Wu

Chapter URL: http://www.nber.org/chapters/c0429

Chapter pages in book: (241 - 260) 


\title{
Merger Activities and Stock Market Valuation in China
}

\author{
Ho-Mou Wu
}

\subsection{Introduction}

The stock markets of China have been developed quickly and in a very different way from other country's stock markets. Since establishment of the markets, China has adopted a dual-track equity system (or so-called parallel market) with nontradable and tradable shares. The nontradable shares are owned by the government agencies of various levels, who are frequently the controlling shareholders of many listed companies. A major feature of the dual-track equity system might be the privatization of these state-owned companies over the least ten years in the stock market. By 2002, it was estimated that 11 percent of listed companies were privately owned. And to the end of 2005, private individuals controlled about 26 percent of listed companies. The changes are brought forth by thousands of transactions, including management buy outs and negotiated transfers of control rights.

The purpose of this chapter is to examine the nature of merger and acquisition (M\&A) activity and analyze how it affects a company's value in China's stock markets. The study of China's M\&A markets can help us to understand better how the stock markets function with the special institutional arrangement of the dual-track equity system. We focus on the most recent period from 2004 to 2005 because M\&A activities have been growing rapidly in this period. The total value of M\&A activities reached 211 bil-

Ho-Mou $\mathrm{Wu}$ is the executive director and Langrun Chair Professor of Economics at the China Center for Economic Research, Peking University.

I am grateful to Julian Wright, Kaoru Hosono, Andy Rose, Taka Ito, and participants of the NBER-EASE conference for helpful suggestions. I also want to thank Yu Zhang and Yun Bai of the China Center for Economic Research (CCER) for research assistance. 
lion RMB in 2004, about twice the M\&A value in 2003, and three times the M\&A value in 2002. In addition, China's stock markets also experienced institutional changes in recent years, with the reform of the dual-track equity system first implemented in mid-2005. As China's stock market went through fundamental changes and the M\&A activities also became very lively in this period, it will be interesting to assess whether M\&As can bring value for listed companies for the period from 2004 to 2005.

In the first part of the chapter, we adopt the event-study method (see Brown and Warner 1985; Bruner 2002) to assess the effects of M\&As in China. We use estimates of abnormal returns, the difference between actual and expected stock returns, to measure the economic effects of M\&As. The expected returns are based on the capital asset pricing model (CAPM), with the market index serving as the benchmark to summarize the influence of marketwide events on the returns of individual stocks. After reviewing thirteen studies of U.S. market data, Jensen and Ruback (1983) found that targets of successful mergers earn significantly positive returns around 20 to 30 percent, but returns to bidding firm shareholders are zero. Their conclusions are also confirmed by more recent works, as summarized by Bruner (2002).

It will be interesting to study whether such a pattern of returns also emerges in China's M\&A market. Loaded with heavy computation of the CAPM models for these individual stocks, this chapter only concentrates on the M\&A activities from 2004 to 2005. In 2004, we collect data of 611 M\&A events involving 499 companies, and in 2005, we find 752 M\&A events involving 587 companies listed on the Shanghai and Shenzhen stock exchanges. We then examine the cumulative abnormal returns (CAR) of M\&A events in depressed markets and upbeat markets.

Because privatization is an important feature in China's stock market, we will study how the ownership structure may affect the CAR of M\&A events. After separating M\&A activities into those initiated by state holding companies and those initiated by privately owned companies, we can find that M\&A activities were value-creating for both private- and statecontrolled firms in 2005, but only for private-controlled firms in 2004 . We also try to explain why this might be so. In addition, we also examine the CAR of acquiring and target firms. We can find that the positive returns of M\&A in 2005 were evenly shared by acquiring and target firms.

The validity of the event-study method relies much on the stock market being efficient such that the CAPM can be used to capture the market influence on individual stocks. However, there exist doubts about the efficiency of China's stock markets as they are in a flux of institutional transformation. And our event studies also lead to mixed results. The alternative avenue of investigation is to use the accounting method. Using the return on assets (ROA), Meeks (1977) found that merger activities brought ROA down for bidding firms. Mueller (1980) found that profitability of acquir- 
ing firms declines and economic gains from mergers appear to be small. Other related works include Healy, Palepu, and Ruback (1992) and Clark and Ofek (1994), who adopt various accounting indicators to study M\&A events.

In the second part of the chapter, we use accounting indicators as a complementary way to understand the effects of M\&As in China. We obtain financial indicators for four years and study whether the financial conditions of M\&A companies demonstrated a deteriorating or improving trend after the M\&A event. We examine how earning per share (EPS), return on assets (ROA), return on equity (ROE), operating cash flows (OCF), free cash flows (FCF), and other indicators change during and after M\&A. We also obtain from financial statements the current ratio, quick ratio, equity multiplier, and liability to equity ratio to study their ability to repay debt before and after merger.

In the next section, we describe M\&A activities in China's stock markets. The economic effects of M\&A as analyzed by the event-study method are discussed in section 7.3. The results from using accounting methods are examined in section 7.4. Section 7.5 provides concluding remarks about our findings.

\subsection{Merger Activities in China's Stock Market}

As of June 2007, China's stock market has a capitalization of US\$2,400 billion, with an upward trend in transaction volume and relative importance in the global financial market. About 900 of the 1,300-plus list companies have their controlling parties from government agencies of various levels. Many of the merger activities involve decisions by government agencies, which is a special feature of China's M\&A market. The dollar amounts of merger activities occurring in the stock market have been growing in recent years, with a significant increase in total values of M\&A activities after 2004 (table 7.1). The total values of M\&A in 2004 and 2005 are about 1 percent of China's gross national product (table 7.2).

We collect all M\&A announcements with values exceeding 10 million RMB and obtain 1,363 events involving 1,086 companies in 2004 and 2005. In 2005, there are 587 firms involved in 752 merger activities (table 7.3).

The size of merger activities, 2002-2005

\begin{tabular}{crc}
\hline Year & Events & Total amount (billion RMB) \\
\hline 2002 & 951 & 77.78 \\
2003 & 934 & 92.31 \\
2004 & 1,541 & 211.69 \\
2005 & 1,219 & 132.32 \\
\hline
\end{tabular}


In 2004, there are 499 firms involved in 611 events of M\&A (table 7.4).

As for the ownership structure, there were 503 events in 2005 with state holding companies as the controlling shareholders and 211 events with privately owned enterprises as the controlling shareholder (table 7.5).

In year 2004, there were 426 events with state holding companies as the controlling shareholders and 142 events with privately owned enterprises as the controlling shareholders (table 7.6).

The reform of the dual-trade equity system was first implemented in May 2005. The stock market also went through a cyclical phase for the period from 2004 to 2005, with Shanghai composite stock index dropping to below the 1,000-point level on June 6, 2005, returning to the level of eight years prior. The market index has been rising ever since then (figure 7.1 and figure 7.2).

During the first half of 2005, before June 3, 300 events of M\&A occurred together with a downward market. For the second half of 2005, there were

Table 7.2

Relative importance of merger activities (billion RMB)

\begin{tabular}{lccc}
\hline & 2004 & 2005 & Growth rate $(\%)$ \\
\hline Total amount & 211.69 & 132.32 & -37.5 \\
GDP & $13,651.5$ & $18,232.1$ & 9.9 \\
Total amount/GDP $(\%)$ & 1.55 & 0.73 & -52.9 \\
\hline
\end{tabular}

Table 7.3

Sample of merger activities in $\mathbf{2 0 0 5}$

\begin{tabular}{lccr}
\hline & Shanghai stock exchange & Shenzhen stock exchange & Total \\
\hline Firms & 361 & 226 & 587 \\
Events & 468 & 284 & 752 \\
\hline
\end{tabular}

Table 7.4 Sample of merger activities in 2004

\begin{tabular}{lccc}
\hline & Shanghai stock exchange & Shenzhen stock exchange & Total \\
\hline Firms & 312 & 187 & 499 \\
Events & 397 & 214 & 611 \\
\hline
\end{tabular}

Table 7.5

Types of controlling shareholders in 2005

\begin{tabular}{lcccrr}
\hline Type & $\begin{array}{c}\text { State holding } \\
\text { company }\end{array}$ & $\begin{array}{c}\text { Privately owned } \\
\text { enterprise }\end{array}$ & $\begin{array}{c}\text { Foreign-owned } \\
\text { company }\end{array}$ & Others & Total \\
\hline Shanghai & 312 & 127 & 4 & 25 & 468 \\
Shenzhen & 191 & 84 & 0 & 9 & 284 \\
Total & 503 & 211 & 4 & 34 & 752 \\
\hline
\end{tabular}


Table 7.6

Types of controlling shareholders in 2004

\begin{tabular}{lccccc}
\hline Type & $\begin{array}{c}\text { State holding } \\
\text { company }\end{array}$ & $\begin{array}{c}\text { Privately owned } \\
\text { enterprise }\end{array}$ & $\begin{array}{c}\text { Foreign-owned } \\
\text { company }\end{array}$ & Others & Total \\
\hline Shanghai & 278 & 91 & 3 & 25 & 397 \\
Shenzhen & 148 & 51 & 0 & 15 & 214 \\
Total & 426 & 142 & 3 & 40 & 611 \\
\hline
\end{tabular}

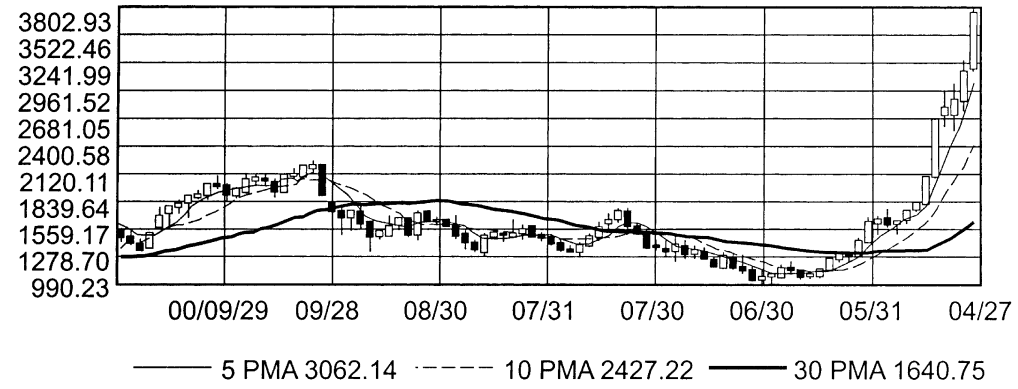

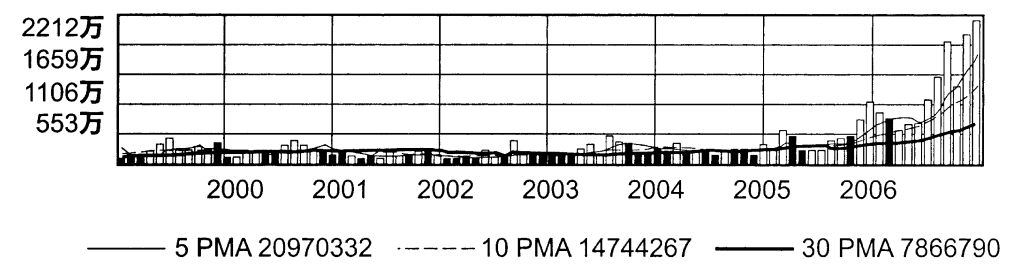

Fig. 7.1 Shanghai Composite Index, 2000-2007

452 events of M\&A in the market with an upward trend (table 7.7). This period also coincided with the early phase of reforming the dual-track equity system. As for year 2004, all M\&A events occurred during a downward market.

In the next section, we will use the factors of ownership structures (as in table 7.5 and table 7.6) and aggregate market performance (as in table 7.7, for 2005) to divide our sample and examine whether the returns of M\&A events may depend on these factors.

\subsection{Stock Market Valuation of M\&A Events}

We divide the event period $\left(t_{0}, t_{2}\right)$ into the preannouncement subperiod $\left(t_{0}, t_{1}-1\right)$, and postannouncement subperiod $\left(t_{1}, t_{2}\right)$, with $t_{1}$ as the date of announcement (see figure 7.3).

In order to use the event-study method, we need to estimate the expected 

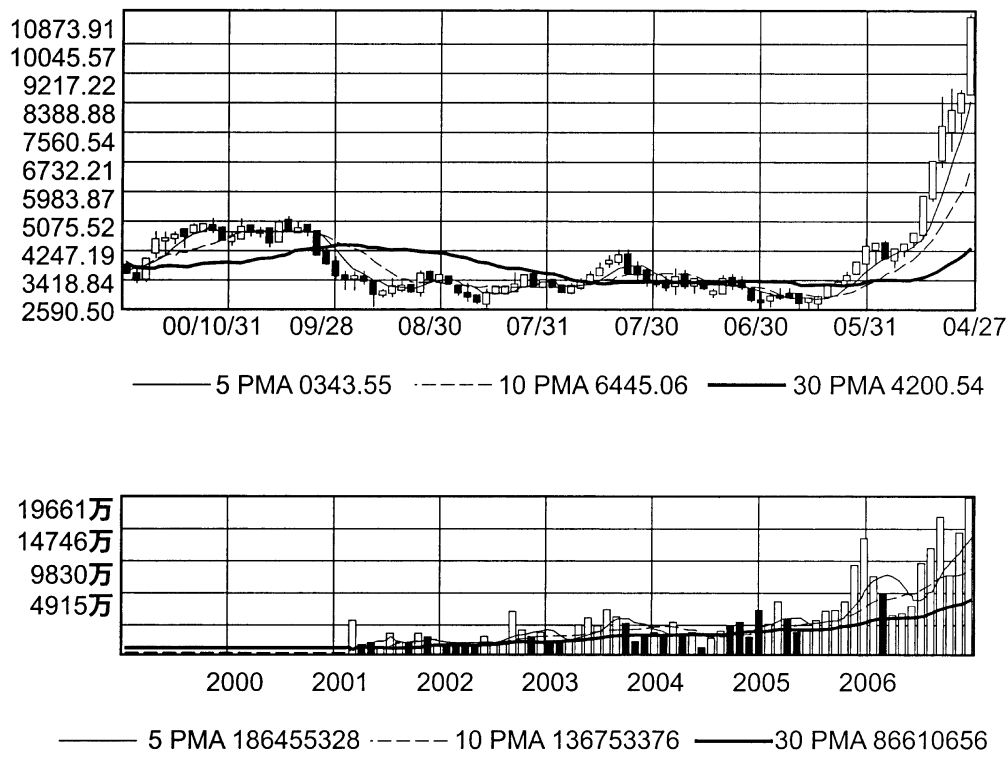

Fig. 7.2 Shenzhen Component Index, 2000-2007

Table 7.7 Merger activities in upward and downward markets in 2005

\begin{tabular}{lccc}
\hline & $\begin{array}{c}\text { Period of downward index } \\
(2005.1 .1-2005.6 .3)\end{array}$ & $\begin{array}{c}\text { Period of upward index } \\
(2005.6 .6-2005.12 .31)\end{array}$ & $\begin{array}{r}\text { Total } \\
\text { Total }\end{array}$ \\
\hline Shanghai & 178 & 290 & 468 \\
Shenzhen & 122 & 162 & 284 \\
Total & 300 & 452 & 752 \\
\hline
\end{tabular}

returns from holding the stocks of M\&A companies if the M\&A event did not occur, which are then used as the benchmark for computing the abnormal returns. The period $\left(t_{0}, t_{1}-1\right)$ before announcing the M\&A at $t=$ $t_{1}$ is used as the basis to estimate the daily expected returns in the CAPM framework:

$$
R_{i t}=\alpha_{i}+\beta_{i} R_{m t}+\varepsilon_{i t} \text { for } t=t_{0} \text { to } t=t_{1}-1, i=1, \ldots, N,
$$

where $R_{m t}$ is the returns on market index in period $t$. We define $r_{i t}=\left(P_{i t}-\right.$ $\left.P_{i t-1}\right) / P_{i t-1}$ and adopt the continuously compounded rate of return $R_{i t}=\ln (1$ $\left.+r_{i t}\right)$ and $R_{m t}=\ln \left(1+r_{m t}\right)$. Then daily abnormal returns (AR) before and after the announcement, that is, $t=t_{0}$ to $t=t_{1}-1$ and $t=t_{1}$ to $t=t_{2}$, can be computed as:

$$
\mathrm{AR}_{i t}=R_{i t}-E\left(R_{i t}\right),
$$

with 


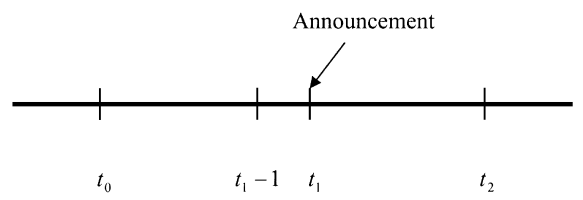

Fig. 7.3 Time line of the event

$$
E\left(R_{i t}\right)=\alpha_{i}+\beta_{i} R_{m t}, \text { for } t=t_{0} \text { to } t=t_{2} .
$$

Then we can aggregate across securities to obtain average abnormal returns (AAR). The associated average cumulative abnormal returns (CAR) is:

$$
\mathrm{CAR}_{t}=\sum_{t=t_{0}}^{t} \mathrm{AAR}_{t},
$$

with

$$
\operatorname{AAR}_{t}=\frac{1}{N} \sum_{i=1}^{N} \mathrm{AR}_{i t} .
$$

In our study, the preannouncement period $(-50,-1)$ corresponds to $\left(t_{0}\right.$, $\left.t_{1}-1\right)$, and the postannouncement period $(0,39)$ corresponds to $\left(t_{1}, t_{2}\right)$ in the preceding formulation.

We first analyze the data for 2004 and find that the AAR and CAR of all merger activities (611 events, see table 7.8 ) were significantly negative (table 7.9).

It is quite surprising to find that the AAR and CAR of M\&A events were significantly negative in 2004. We next analyze the CAR of all merger activities in 2005 (752 events, see table 7.10). In contrast, we discover that AAR and CAR were significantly positive (table 7.11).

In order to better understand how average abnormal returns (AAR) and cumulative abnormal returns (CAR) evolved over time, we also plot them for 2004 and 2005 separately (figure 7.4 and figure 7.5). This constitutes a very interesting phenomenon for China's M\&A activities: either small positive returns or significantly negative returns, as in 2005 and 2004. It is quite different from the experiences of other countries (see Bruner 2002; Bris and Cabolis 2003; Agrawal, Jaffe, and Mandelker 1992; Datta, Pinches, and Narayanan 1992; Dodd and Ruback 1977; Gillan, Kensinger, and Martin 2000; Jarrell, Brickley, and Netter 1988; Leeth and Borg 2000; Mulherin and Boone 2000; Schwert 1996).

In addition, we find that transaction volume of the stocks involved in M\&A jumped at the date of announcement $(t=0)$ and stayed quite stable on other days in 2005, and the situation was also similar in 2004 (figure 7.6). One may conclude that the stock market more or less treated the announcement of M\&A events as a piece of new information in this period.

In order to understand why the CAR is negative in 2004, we separate all events into various industries, but do not find significant differences across 
Table 7.8

Descriptive statistics of all merger activities in 2004

\begin{tabular}{ccccc}
\hline & Minimum & Maximum & Mean & Standard deviation \\
\hline AAR & -0.0020412 & 0.0018957 & -0.0002216 & 0.0009668 \\
CAR & -0.0199465 & 0.0011907 & -0.0066257 & 0.0058423 \\
\hline
\end{tabular}

Table 7.9

Significance test of all merger activities in 2004 (test value $=0$ )

\begin{tabular}{cccccc}
\hline & & & \multicolumn{2}{c}{$\begin{array}{c}95 \% \text { confidence interval } \\
\text { of the difference }\end{array}$} \\
\cline { 4 - 6 } & $t$ & Significance (2-tailed) & Mean difference & Lower & Upper \\
\hline AAR & -2.1747762 & 0.032299 & -0.0002216 & -0.0004241 & $-1.914 \mathrm{E}-05$ \\
CAR & -10.75884 & $8.799 \mathrm{E}-18$ & -0.0066257 & -0.0078493 & -0.005402 \\
\hline
\end{tabular}

Table 7.10

Descriptive statistics of all merger activities in $\mathbf{2 0 0 5}$

\begin{tabular}{ccccc}
\hline & Minimum & Maximum & Mean & Standard deviation \\
\hline AAR & -0.002816 & 0.0055395 & 0.0001699 & 0.0011215 \\
CAR & -0.007585 & 0.0189335 & 0.0057595 & 0.0078968 \\
\hline
\end{tabular}

Table 7.11

Significance test of all merger activities in 2005 (test value $=0$ )

\begin{tabular}{cccccc}
\hline & & & \multicolumn{2}{c}{$\begin{array}{c}95 \% \text { confidence interval } \\
\text { of the difference }\end{array}$} \\
\cline { 4 - 6 } & $t$ & Significance (2-tailed) & Mean difference & Lower & Upper \\
\hline AAR & 1.429 & 0.157 & 0.0001699 & $-6.64 \mathrm{E}-05$ & 0.0004061 \\
CAR & 6.881 & 0 & 0.0057595 & 0.0040961 & 0.007423 \\
\hline
\end{tabular}

industries. However, we discover that the major source of the negative returns might be due to the ownership structure. Those events with state holding companies as the final shareholder (called the first kind) had a large negative CAR (figure 7.7), while those privately owned enterprises as the final shareholder (called the second kind) demonstrated a significantly positive CAR (figure 7.8). Because the weight of the first kind (426 out of 611 events) is larger than the second kind (142 out of 611 events), we have a combined impact of negative returns for 2004. This may lead us to consider the M\&A events initiated by state holding companies as not so focused on enhancing the value of the firm, while those done by privately owned enterprises might be more motivated by efficiency concerns. It may be due to the fact that the government may want to achieve a different objective. 


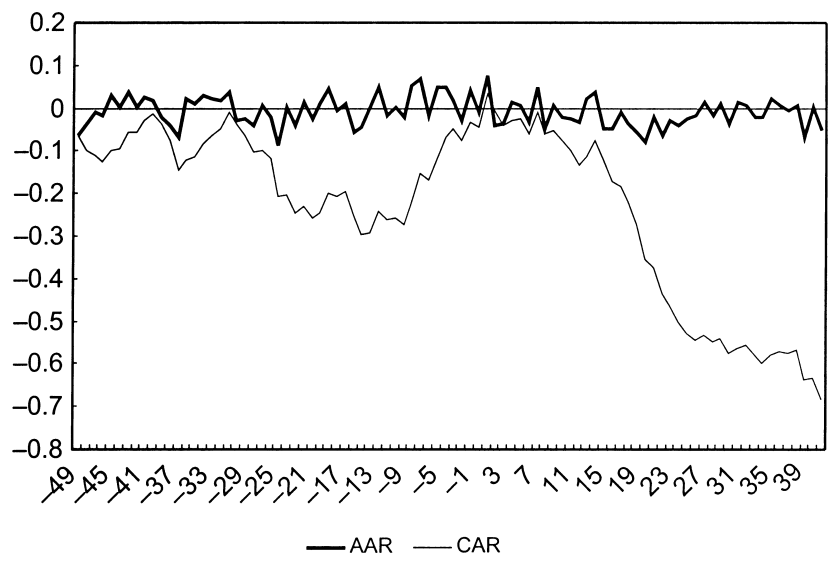

Fig. 7.4 CAR of all merger activities (average CAR $=-0.662 \%$ ) in 2004

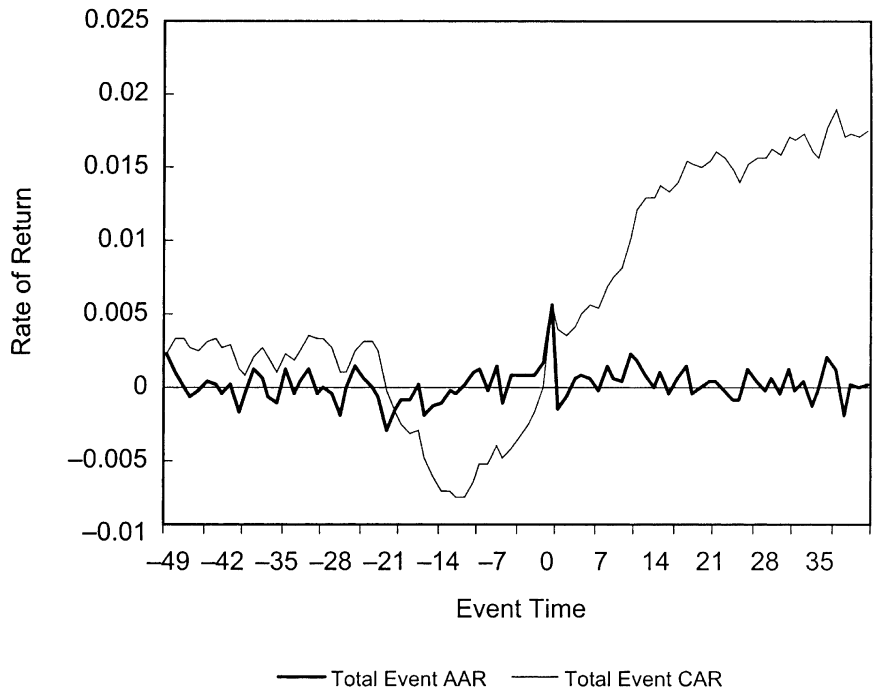

Fig. 7.5 CAR of all merger activities (average CAR $=\mathbf{0 . 5 7 5} \%$ ) in 2005

In 2005, we also examine whether ownership structures had influence on the value created through M\&A. We find that M\&A activities with the state as the controlling party (CAR at $t=40$ is 1.83 percent) and those with the private enterprises as the controlling party (CAR at $t=40$ is 1.11 percent) all produced positive returns (figure 7.9 and figure 7.10). This may demonstrate that the state holding companies paid more attention to value creation in their M\&A activities and that the ownership structure was not such a significant factor in influencing the values of M\&A events in 2005. 
Transaction Volume

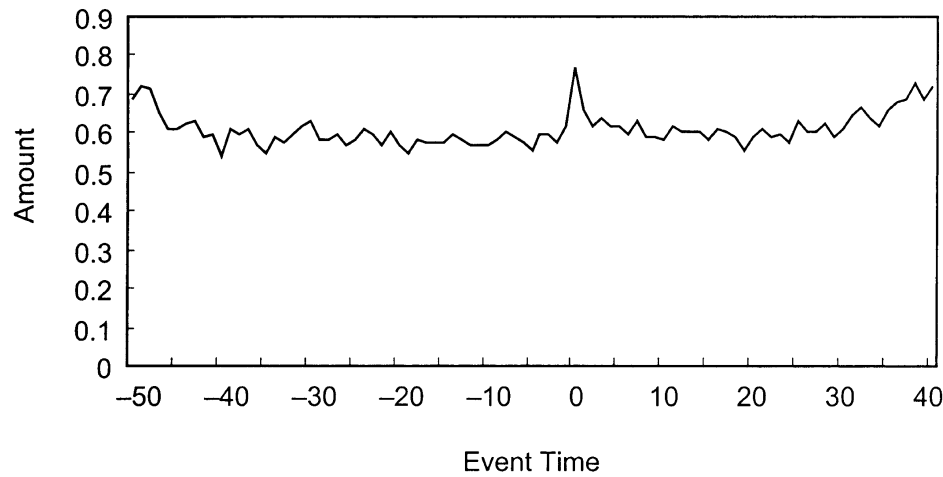

Fig. 7.6 Transaction volume, 2005

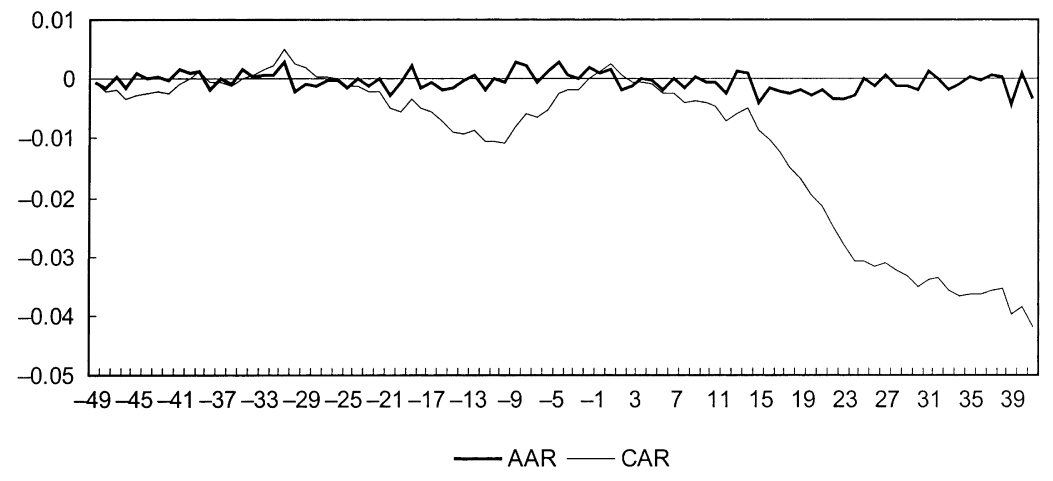

Fig. 7.7 State holding companies as the controlling party, 2004

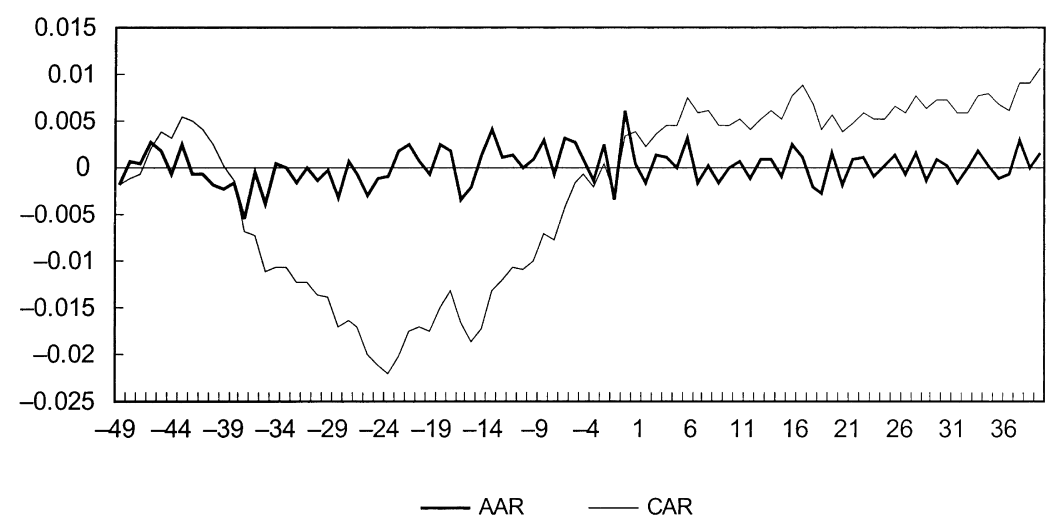

Fig. 7.8 Privately owned enterprises as the controlling party, 2004 
In order to understand better how the stock market evaluates merger activities when they produce positive returns, we separate the sample into acquiring firms and target firms in 2005. The average CARs of both types are less than 1 percent (table 7.12 and table 7.13).

In contrast to the findings with U.S. data, with the sample of China's 2005 M\&A events, the bidders in China obtained a significantly positive but small return (CAR at $t=40$ is 1.68 percent). Also in contrast to the U.S. market, the target firms' returns (CAR at $t=40$ is 2.03 percent) were

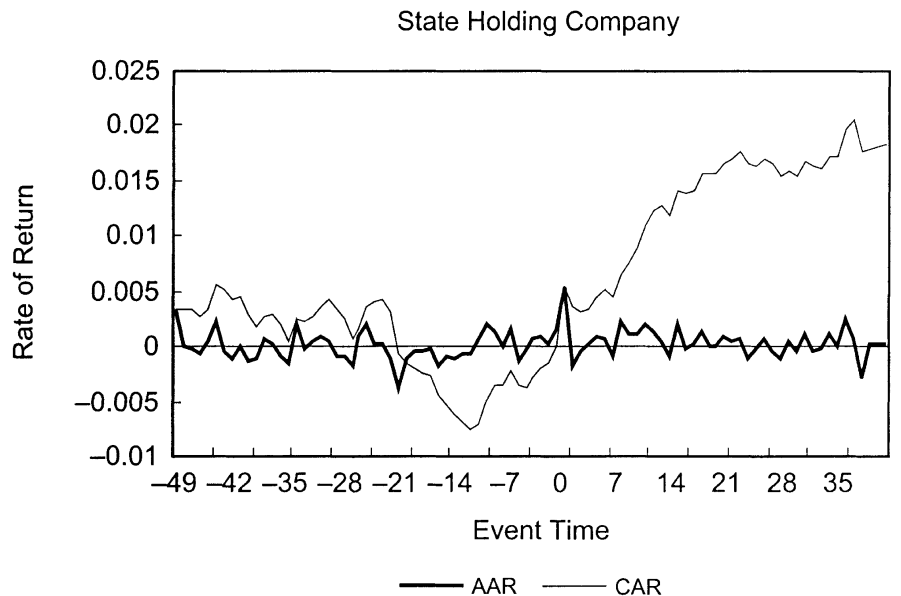

Fig. 7.9 State holding company as the controlling party (average CAR = $0.625 \%), 2005$

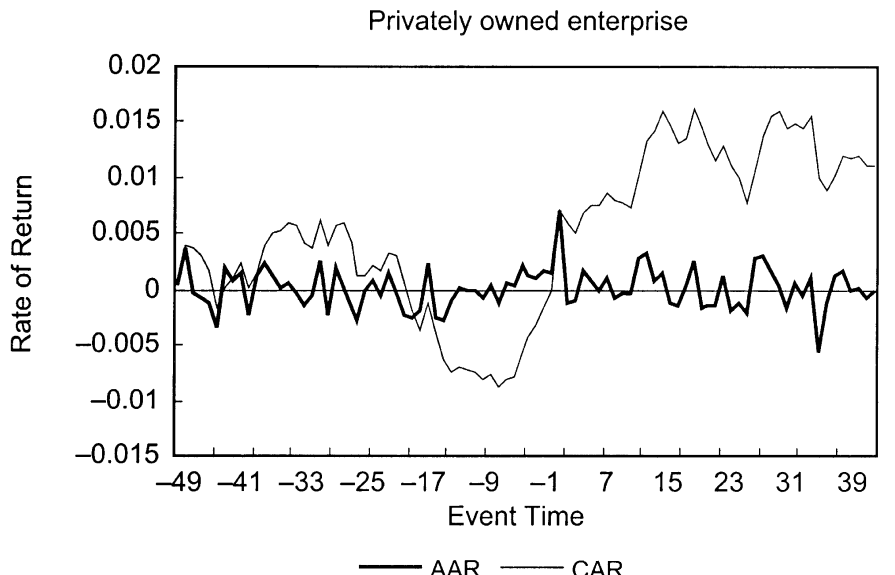

Fig. 7.10 Privately owned enterprise as the controlling party (average CAR = $0.504 \%), 2005$ 
CAR of acquiring firms, 2005 (test value $=0$ )

\begin{tabular}{|c|c|c|c|c|c|c|}
\hline & \multirow[b]{2}{*}{$t$} & \multirow[b]{2}{*}{ df } & \multirow[b]{2}{*}{ Significance (2-tailed) } & \multirow[b]{2}{*}{ Mean difference } & \multicolumn{2}{|c|}{$\begin{array}{l}95 \% \text { confidence interval } \\
\text { of the difference }\end{array}$} \\
\hline & & & & & Lower & Upper \\
\hline AAR & 0.958 & 88 & 0.341 & 0.0001666 & -0.000179 & 0.0005124 \\
\hline CAR & 8.948 & 88 & 0 & 0.0064602 & 0.0050255 & 0.0078949 \\
\hline
\end{tabular}

Table 7.13

CAR of target firms, 2005

\begin{tabular}{|c|c|c|c|c|c|c|}
\hline & \multirow[b]{2}{*}{$t$} & \multirow[b]{2}{*}{$\mathrm{df}$} & \multirow[b]{2}{*}{ Significance (2-tailed) } & \multirow[b]{2}{*}{ Mean difference } & \multicolumn{2}{|c|}{$\begin{array}{l}95 \% \text { confidence interval } \\
\text { of the difference }\end{array}$} \\
\hline & & & & & Lower & Upper \\
\hline AAR & 1.185 & 88 & 0.239 & 0.000227 & -0.000154 & 0.0006076 \\
\hline CAR & 4.946 & 88 & 0 & 0.0051033 & 0.0030527 & 0.0071539 \\
\hline
\end{tabular}

also much smaller than their counterparts in the United States, where the target firms can earn up to 20 to 30 percent (figure 7.11 and figure 7.12).

The other possible deciding factor for the different M\&A performances in 2004 and 2005 may be the aggregate market performance. While the market in 2004 had a downward trend over the whole period, the market in 2005 witnessed both a depressed market (before June 3) and an upbeat market. As a possible channel to discern the different M\&A performances between 2004 and 2005, we separate our 2005 sample into a period with downward index and another with upward index (figure 7.13 and figure 7.14). We find that merger activities increase a company's value both in a depressed market (CAR at $t=40$ is 3.19 percent) and in an upbeat market (CAR at $t=40$ is 0.78 percent). Because we use the CAPM as the benchmark to compute excess returns, this demonstrates that after correcting market conditions, M\&A events had positive returns in both depressed and upbeat markets in 2005. It is different from the performance of 2004, when M\&A activities produced negative returns in a depressed market.

Because the period with upward trend coincided with the early phase of reforming the dual-track equity system, our results (from figure 7.13 and figure 7.14) may demonstrate that the reform itself did not have a direct impact on M\&A performance. However, the reform might have indirect and lasting influences on the improvement of efficiency in China's stock market.

Besides using the event period $(-49,40)$, we also tried different windows such as $(-24,20)$ and $(-12,10)$. We also tried to set the preannouncement period to $\left(t_{0}, t_{1}-5\right)$, allowing the possibility of leak of information before announcement. However, the results are quite similar, and we omit them in this version of the paper. 


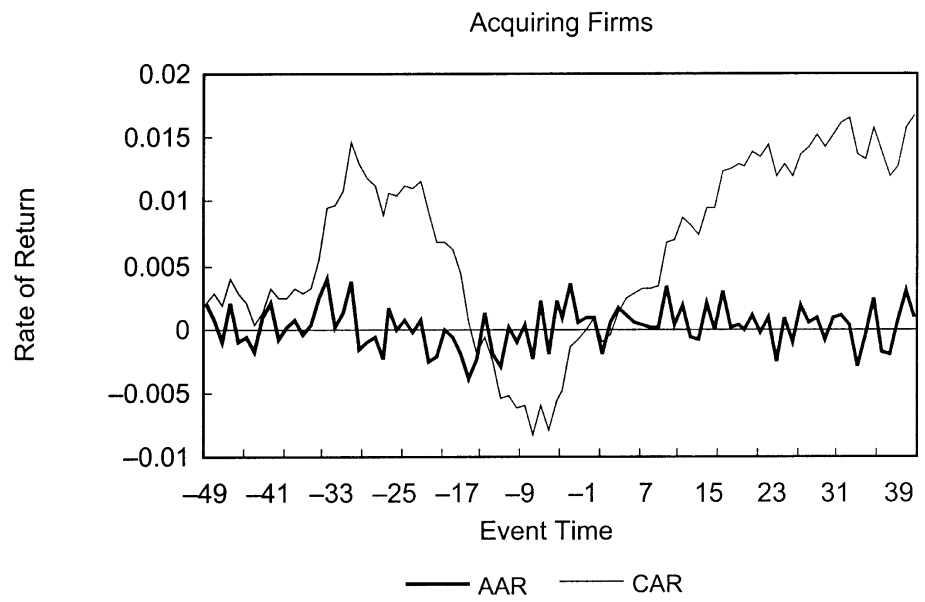

Fig. 7.11 CAR of acquiring firms (average CAR $=0.641 \%$ ), 2005

Target Firms

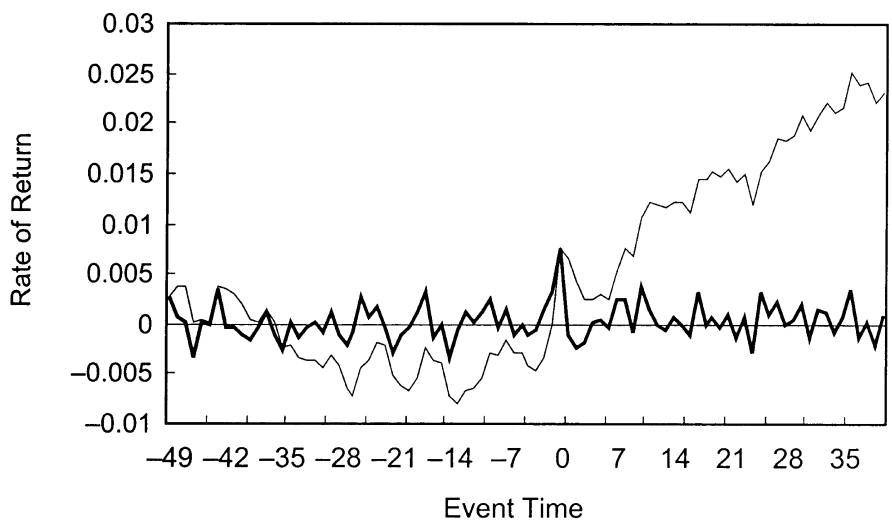

- AAR - CAR

Fig. 7.12 CAR of target firms (average CAR $=0.508 \%$ ), 2005

We can conclude this section by noting that the event-study method produces some rather interesting results for the valuation of merger activities in China. We found that the M\&A activities produced negative returns in 2004, but positive, although small, returns in 2005. Although China's stock market may not have reached the level of efficiency in advanced economies, our preliminary investigation demonstrates that its efficiency has been improved from 2004 to 2005 . This chapter also shows that stock market valuation of all merger activities in China is mildly positive in 2005, which may also help to enhance the allocative role of China's stock market in the future. 
Period of Downward Index (2005.1.1-2005.6.3)

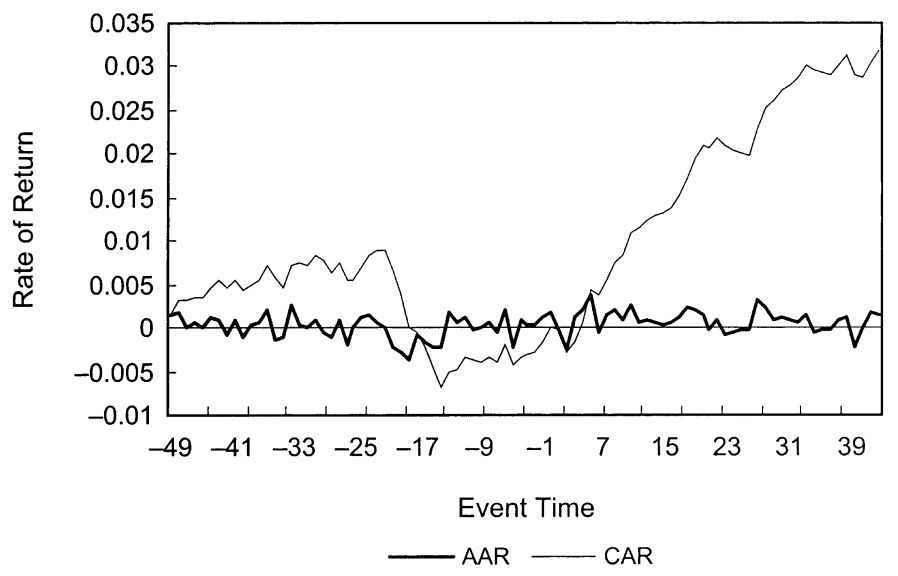

Fig. 7.13 Period of downward index (average CAR $=0.963 \%$ ), 2005

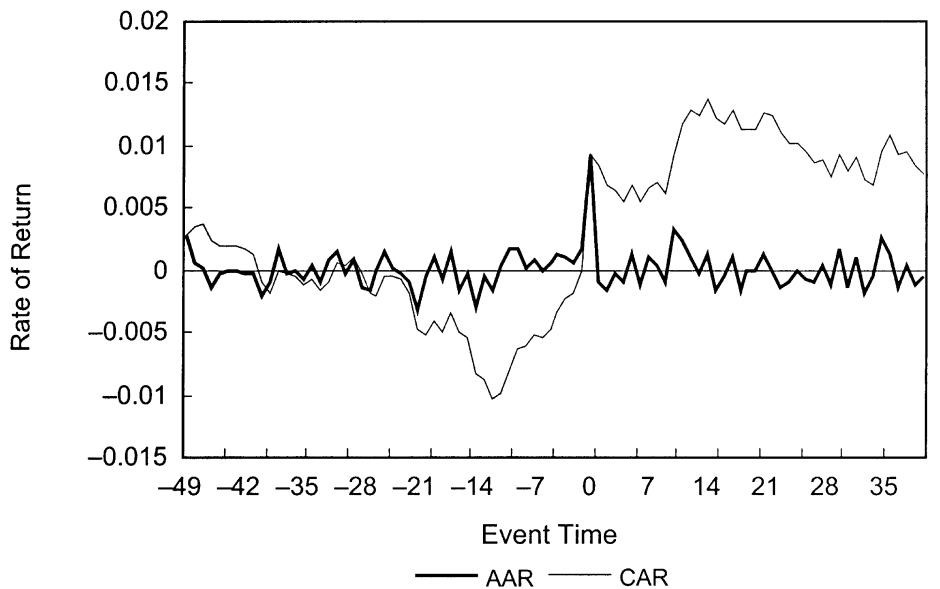

Fig. 7.14 Period of upward index (average CAR $=0.312 \%$ ), 2005

\subsection{Accounting Indicators Before and After Mergers}

In this section, we study the financial conditions of merging firms. Because the returns on M\&A events in 2004 are negative, we only concentrate on verifying whether financial conditions also improve for the M\&A events with positive returns in 2005. We collect accounting information from 2002 to 2006 for the 587 firms involved in the M\&A activities in 2005. First, we obtain EPS, earning before interest and taxes (EBIT) per share, and cash flow per share of all firms we studied in the last section. From table 7.14 and 


\begin{tabular}{lccccc}
\hline & 2002 & \multicolumn{1}{c}{2003} & \multicolumn{1}{c}{2004} & \multicolumn{1}{c}{2005} & 2006 \\
\hline EPS & 0.161864 & 0.13994 & 0.13541 & 0.09876 & 0.153206 \\
EBIT per share & 0.291789 & 0.284257 & 0.291105 & 0.267955 & 0.329258 \\
Cash flow per share & 0.073534 & 0.043986 & 0.040717 & -0.01556 & 0.027136
\end{tabular}

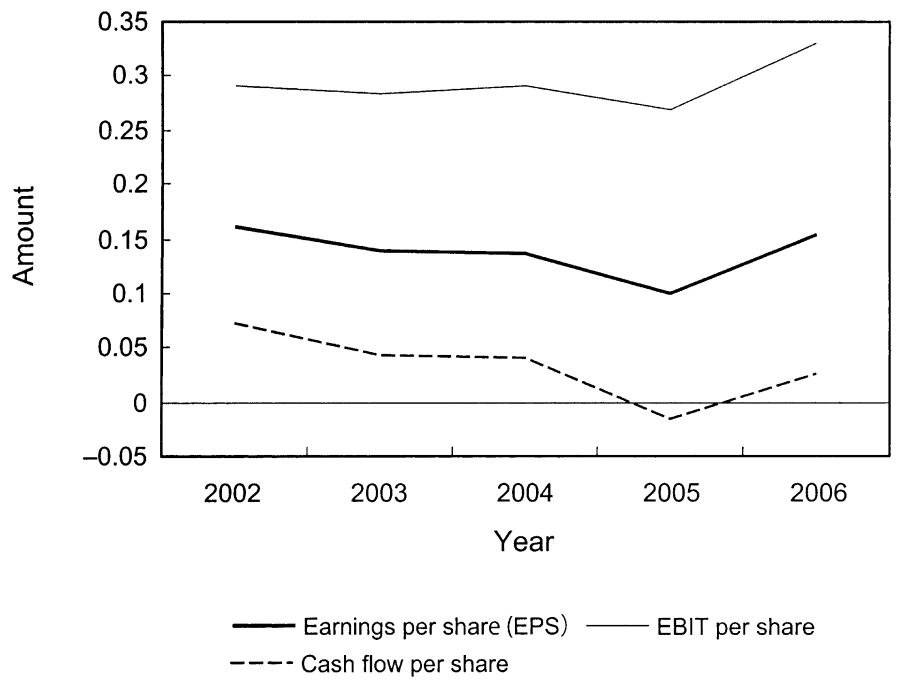

Fig. 7.15 Accounting information (per share) for all merging firms

figure 7.15, we can see clearly that all three indicators decline in 2005, the year of the merger, and improve in 2006, the year after the merger. The growth rates of the last two years are -27 percent and 55 percent for EPS, -8 percent and 23 percent for EBIT per share, and -138 percent and 270 percent for cash flow per share. These three indicators demonstrate a consistent pattern before, during, and after the merger.

Next, we study the earning ability of these firms, which forms the basis of a firm's strong financial condition. From table 7.15 and figure 7.16, we can find that EBIT increases over the whole period but ROE and ROA both decrease in 2005 and then improve in 2006. The growth rates for the last two years are -71 percent and 273 percent for ROE and -14 percent and 25 percent for ROA. In contrast to the findings in the U.S. market, our results show a clear pattern for the 587 firms combined together.

The ability to service debt is another way to measure the firm's financial conditions. We first study the current ratio, which is current asset (cash, cash equivalent, accounts receivable, and inventory) divided by current liability (short-term loans and accounts payable). Because inventory is not 
Table 7.15

Earning ability, 2002-2006

\begin{tabular}{lccccc}
\hline & 2002 & 2003 & 2004 & 2005 & 2006 \\
\hline EBIT (billion RMB) & 0.214956 & 0.253167 & 0.331346 & 0.368624 & 0.447996 \\
Return of equity & 4.769542 & 4.070747 & 3.650489 & 1.049658 & 3.917524 \\
Return of assets & 4.943371 & 4.563602 & 4.337534 & 3.726122 & 4.671156 \\
\hline
\end{tabular}

Analysis of profitability

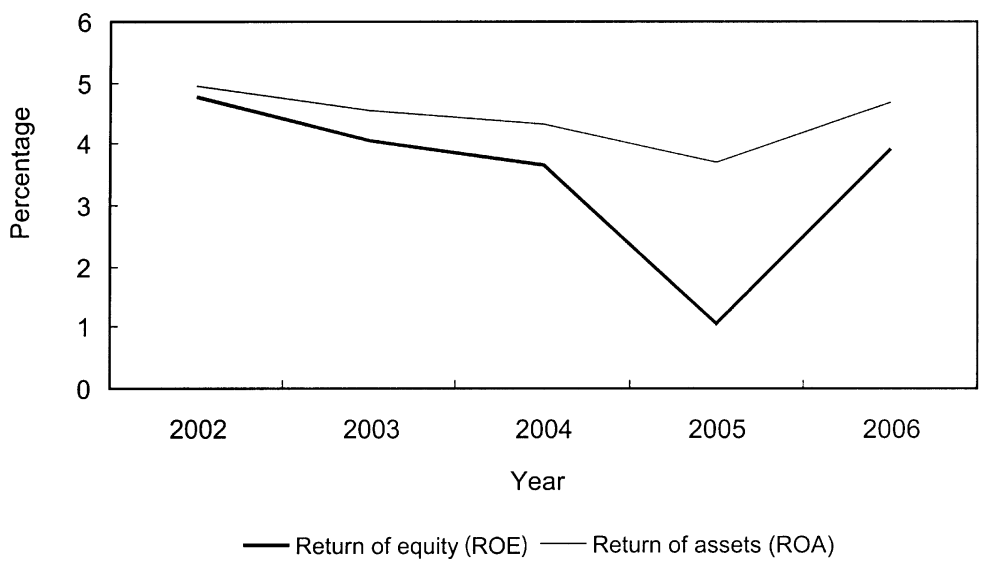

Fig. 7.16 Earning ability of all merging firms, 2002-2006

easy to convert into cash, the quick ratio, which does not include inventory in the numerator, is also computed for our data set. These two ratios measure the firm's ability to repay short-term debt.

The normal range of the current ratio is within 0.5 to 2.0. For our 587 firms, their average is within the safe range, but it clearly declines over time. The quick ratio should have its ideal range around 1 . We can see that the average of quick ratio fell below 1 after the merger in 2005. Both ratios of these merging firms clearly become worse after 2005. So the short-term ability of these merging firms to repay debt has declined after the merger (see table 7.16).

We use the liability to equity ratio and the equity multiplier to represent the long-term ability to repay debt. As the liability to equity ratio increases, the ability to repay debt has declined, as shown in figure 7.17, before and after the merger. In the mean time, as the equity multiplier, which is defined to be the ratio of asset to equity, rises in the firm's reliance on debt has also increased (figure 7.18).

Before closing this section, we present the cash flows of these firms over 


\begin{tabular}{lccccc}
\hline & 2002 & 2003 & 2004 & 2005 & 2006 \\
\hline Liability to equity ratio & 44.8117 & 47.34732 & 50.01123 & 52.28126 & 52.64088 \\
Current ratio & 1.632192 & 1.525752 & 1.427801 & 1.333356 & 1.32292 \\
Quick ratio & 1.240658 & 1.123622 & 1.021103 & 0.933706 & 0.889238 \\
Equity multiplier & 2.0863 & 2.151938 & 2.229744 & 2.466456 & 2.89927 \\
\hline
\end{tabular}

Analysis of solvency—Liability to equity ratio

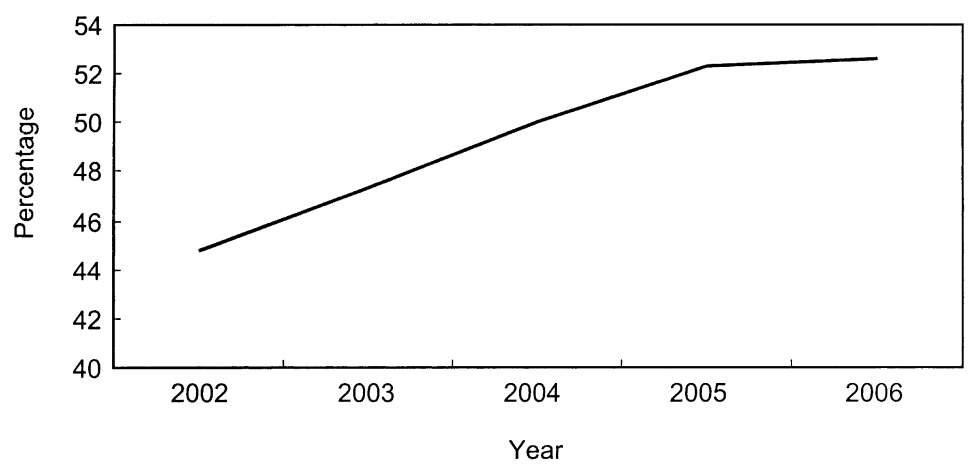

L Liability to equity ratio

\section{Fig. 7.17 Liability equity ratios}

\section{Analysis of solvency}

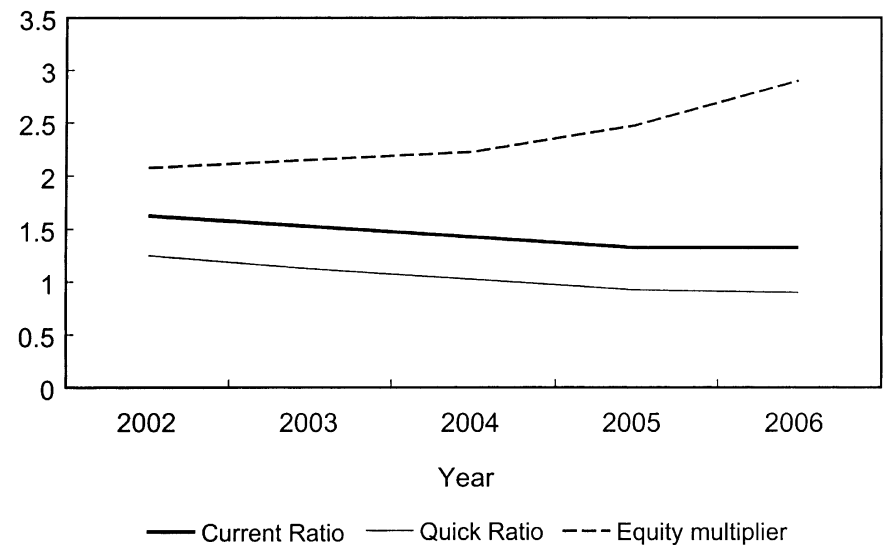

Fig. 7.18 Ability to repay debt 
Table 7.17

Cash flows, 2002-2006 (100 million RMB)

\begin{tabular}{lccccc}
\hline & 2002 & 2003 & 2004 & 2005 & 2006 \\
\hline Operating cash flow & 3.244178 & 3.807216 & 4.599242 & 5.102536 & 5.91053 \\
Free cash flow of firm & 0.373923 & 0.417455 & -0.25308 & 0.549061 & 0.815731 \\
\hline
\end{tabular}

Cash flow (billion)

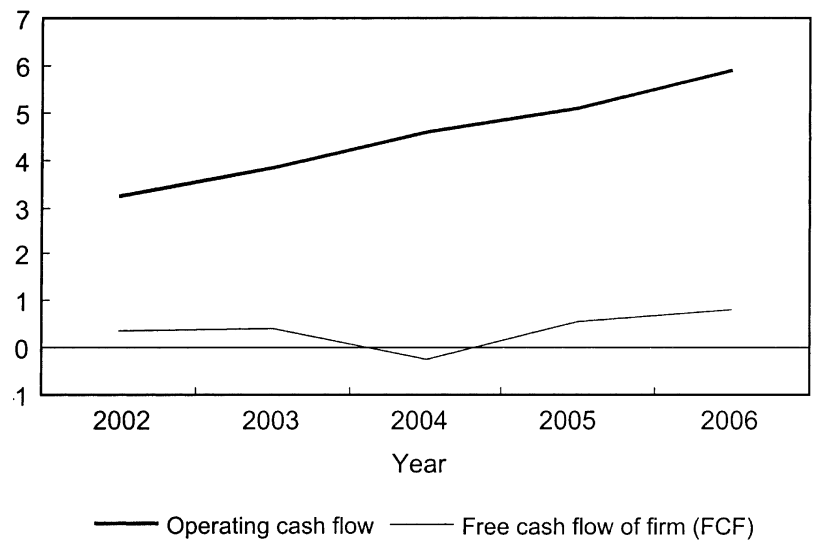

Fig. 7.19 Cash flows, 2002-2006

the four-year horizon. Both operating cash flows (OCF), which is EBIT plus depreciation minus taxes, and free cash flows (FCF), which is OCF minus any expenditures necessary to maintain the firm's operating assets, measure the firm's profitability before or after deducting investment expenditures. From table 7.17 and figure 7.19, we can see that the profitability of the merging firms has improved after the merger in 2005.

By using the accounting method in this section, we can conclude that the financial conditions of the M\&A firms showed a certain degree of decline in the first year of the M\&A event, but improve in the next year. However, the short-term and long-term ability to repay debt declined without a clear sign of improvement after the merger.

\subsection{Concluding Remarks}

In this chapter, we examine 1,363 M\&A events involving 1,086 companies traded on the Shanghai and Shenzhen stock exchanges from 2004 to 2005. Our event-study analysis indicates that within the event period $(-50$ days, 40 days), M\&A activities produced negative returns in 2004, but positive, although small, returns in 2005. For the 2004 data with negative returns in aggregate, we discover that M\&A activities controlled by state hold- 
ing companies were responsible for producing those negative returns, while the M\&A events initiated by privately owned enterprises had positive returns. For the 2005 data with positive returns in aggregate, both types of M\&A activities produced positive but small returns.

We also separate the 2005 data into acquiring and target firms and discover that the acquiring firms and target firms received, respectively, 1.68 percent and 2.03 percent in China, while the target firms often received over 20 percent of returns in the U.S. market. In addition, we found that the M\&A companies' industries and the market's aggregate performance did not have significant impacts on the returns of M\&A events.

Our results may demonstrate that China's stock market might not have reached the level of efficiency of the more-advanced economies, but its efficiency in assessing the value of M\&A activities might have been improved from 2004 to 2005. The stock market valuation of M\&A events became mildly positive in 2005 , which may help to enhance the allocative role of China's stock market in the future.

Analyzing accounting indicators within a longer observation period (four years), we also discover that the financial conditions of companies involved in M\&A in 2005 showed a certain degree of decline in the first year of the M\&A event, but an obvious improvement in the following year. However, the short-term and long-term ability to repay debt declined without a clear sign of improvement after the merger.

This chapter serves as a pioneering study for China's M\&A activities. There are many interesting phenomena discovered in this preliminary study. However, precise measurements and more studies with control groups to disaggregate the total effects should be included in the future work. As China's stock market grows rapidly with fundamental institutional changes, more in-depth studies will help us to understand how this major market functions in transition.

\section{References}

Agrawal, A., J. F. Jaffe, and G. N. Mandelker. 1992. The post-merger performance of acquiring firms: A re-examination of an anomaly. Journal of Finance 47:1605-21.

Bris, A., and C. Cabolis. 2003. Adopting better corporate governance: Evidence from cross-border mergers. Paper presented at European Finance Association conference. Glasgow, Scotland.

Brown, S. J., and J. B. Warner. 1985. Using daily stock returns: The case of event studies. Journal of Financial Economics 14:3-31.

Bruner, R. 2002. Does M\&A pay? A survey of evidence for the decision-maker. Journal of Applied Finance 12:48-68.

Clark, K., and E. Ofek. 1994. Mergers as a means of restructuring distressed firms: An empirical investigation. Journal of Financial and Quantitative Analysis 29 (4): $541-65$. 
Datta, D. K., G. E. Pinches, and V. K. Narayanan. 1992. Factors influencing wealth creation from mergers and acquisitions: A meta-analysis. Strategic Management Journal 13:67-86.

Dodd, P., and R. Ruback. 1977. Tender offers and stockholder returns: An empirical analysis. Journal of Financial Economics 5:351-74.

Gillan, S. L., J. W. Kensinger, and J. D. Martin. 2000. Value creation and corporate diversification: The case of Sears, Roebuck \& Co. Journal of Financial Economics 55:103-37.

Healy, P. M., K. G. Palepu, and R. S. Ruback. 1992. Does corporate performance improve after mergers? Journal of Financial Economics 31:135-75.

Jarrell, G. A., J. A. Brickley, and J. M. Netter. 1988. The market for corporate control: The empirical evidence since 1980. Journal of Economic Perspectives 2 (1): 49-68.

Jensen, M. C., and R. S. Ruback. 1983. The market for corporate control: The scientific evidence. Journal of Financial Economics 11:5-50.

Leeth, J. D., and J. R. Borg. 2000. The impact of takeovers on shareholder wealth during the 1920's merger wave. Journal of Financial and Quantitative Analysis 35 (2): 217-38.

Meeks, G. 1977. Disappointing marriage: A study of the gains from merger. Cambridge, UK: Cambridge University Press.

Mueller, D. 1980. The determinants and effects of mergers: An international comparison. Cambridge, MA: Oelgeschlager, Gunn \& Hain.

Murlherin, J. H., and A. L. Boone. 2000. Comparing acquisitions and divestitures. Journal of Corporate Finance 6:117-39.

Schwert, G. W. 1996. Markup pricing in mergers and acquisitions. Journal of Financial Economics 41:153-62.

\section{Comment Kaoru Hosono}

Using merger and acquisition (M\&A) events involving listed companies in China during the 2004 to 2005 period, the author found the following facts:

1. The cumulative abnormal return (CAR) of the M\&A firms was significantly negative in 2004, while it was significantly positive in 2005.

2. In 2004, M\&A activities initiated by state-owned companies had negative returns, while those done by privately owned companies had positive returns. In 2005, both types of companies had positive returns from M\&As.

3. In 2005, the CARs of acquiring and target firms were both significantly positive, though small.

4. For the companies involved in $2005 \mathrm{M} \& \mathrm{~A}$ events, return on assets (ROA) and other financial conditions showed a decline in the year of M\&A, but recovered in the following year. On the other hand, leverage increased after M\&A. 